\title{
Potensi Manipulasi Pendapatan Menggunakan Model Beneish M-Score, Studi Kasus pada Laporan Keuangan PT Garuda Indonesia Tbk., Tahun 2017-2018
}

\author{
Budi Nugroho ${ }^{1, *}$ \\ 1,* Universitas Bina Insani: Jalan Raya Siliwangi no.6 Rawa Panjang Bekasi Timur \\ 17114 Indonesia. Telp. (021) 82436886 / (021) 82436 996. e-mail: \\ budi.nugroho@rocketmail.com \\ *Korespondensi: email: budi.nugroho@ rocketmail.com
}

Diterima: 30 Maret 2020; Review: 20 April 2020; Disetujui: 01 Mei 2020

Cara Sitasi: Nugroho, B. 2020. Potensi Manipulasi Pendapatan Menggunakan Model Beneish M-Score, Studi Kasus pada Laporan Keuangan PT Garuda Indonesia Tbk., Tahun 2017-2018. Jurnal Online Insan Akuntan. Vol. 5 (1): 73-82.

\begin{abstract}
Abstrak: Penelitian ini menggunakan model Beneish m-score untuk mendeteksi potensi manipulasi pendapatan pada laporan keuangan tahunan PT Garuda Indonesia Tbk periode tahun 2018. Tujuan penelitian adalah untuk mengungkapkan kemungkinan adanya potensi manipulasi pendapatan pada laporan keuangan PT Garuda Indonesia, Tbk, untuk periode tahun buku 2018. Berdasarkan hasil pengolahan data, nilai m-score dari laporan keuangan perusahaan adalah -0,49, yang mana lebih besar dari nilai acuan $-2,22$, sehingga dapat disimpulkan bahwa berdasarkan model ini, terdapat potensi manipulasi pendapatan pada laporan keuangan PT Garuda Indonesia Tbk., untuk periode tahun buku 2018. Penggunaan model ini untuk mendeteksi adanya potensi manipulasi pendapatan pada laporan keuangan perusahaan sangat berguna bagi pemegang saham,investor, dan kreditur.
\end{abstract}

Kata Kunci: Beneish m-score, manipulasi, pendapatan, laporan keuangan.

Abstract: The research use Beneish m-score model to detect potential income manipulation on annual financial statement of PT Garuda Indonesia, for the year 2018. The objective of this research was to uncover potential income manipulation on the financial statement. Based on data calculation, the $m$ score value was -0,49, which higher than reference value-2,22, therefore it can be concluded that there was potential income manipulation in PT Garuda Indonesia, for the year 2018. The application of this model in order to detect potential income manipulation in the company financial statement might be useful for shareholders, investors, and creditors.

Keywords: Beneish m-score, manipulation, income, financial statement.

\section{Pendahuluan}

Laporan keuangan suatu entitas yang bersumber dari data-data akuntansi menyajikan informasi finansial kepada pengguna internal, seperti direktur, manajer, dan supervisor, maupun pengguna eksternal seperti investor dan kreditur (Weygandt, Kieso, Kimmel, 2016). 
Salah satu bentuk laporan keuangan adalah Laporan Laba Rugi atau Income Statement, yang menyajikan pendapatan dan beban dengan hasil akhir berupa laba atau rugi bersih untuk suatu periode waktu tertentu.

Pendapatan adalah asersi dalam unit moneter atas hasil usaha suatu entitas, baik dalam bentuk barang maupun jasa, pada suatu periode tertentu. Menurut PSAK 23, definisi pendapatan adalah arus masuk bruto dari manfaat ekonomi yang timbul dari aktivitas normal perusahaan selama satu periode jika arus masuk tersebut mengakibatkan kenaikan ekuitas, yang tidak berasal dari kontribusi penanam modal. Pendapatan hanya meliputi arus masuk bruto dari manfaat ekonomi yang diterima dan dapat diterima oleh entitas untuk dirinya sendiri.

Bagi entitas usaha, pendapatan merupakan komponen yang sangat penting karena selalu menjadi fokus dalam aktivitas menghasilkan laba sebagai tujuan utama didirikannya suatu entitas usaha. Oleh karena itu, di samping usaha untuk meningkatkan pendapatan melalui upaya-upaya pemasaran dan penjualan, pengakuan pendapatan dan penyajiannya dalam laporan keuangan entitas selalu menjadi perhatian para pemangku kepentingan, termasuk para pemegang saham, investor, maupun kreditur (Statement of Financial Accounting Concept/SFAC No.1).

Data historis menunjukkan bahwa beberapa perusahaan besar, meski telah menyajikan laporan keuangan yang sudah diaudit dan mendapatkan opini wajar tanpa pengecualian oleh akuntan publik, tidak menjadi jaminan bahwa perusahaan terbebas dari potensi manipulasi laporan keuangan, contohnya: Enron, Xerox, Worldcom, Adelphia Communication, Duke Energy, dan lain-lain.

PT Garuda Indonesia, Tbk., merupakan satu-satunya perusahaan penerbangan nasional Indonesia yang sudah listed di Bursa Efek Indonesia. Sebagai flag carrier Indonesia, di samping dimiliki publik, perusahaan ini sebagian besar sahamnya dimiliki oleh pemerintah Indonesia.

Laporan Keuangan PT Garuda Indonesia, Tbk. Tahun 2018, tercatat membukukan laba bersih USD 809 ribu, yang mana berbeda jauh dengan kinerja di tahun sebelumnya, di mana perusahaan mengalami kerugian sebesar USD 216,58 juta. Hal ini menarik perhatian publik, termasuk dalam hal ini pemegang 
saham, pemerintah, pihak regulator maupun pengawas serta masyarakat umum. Penelitian ini mencoba untuk melihat apakah terdapat potensi manipulasi pendapatan pada laporan keuangan perseroan.

\section{Landasan Teori}

Association of Certified Fraud Examiners (ACFE) mendefinisikan financial statement fraud sebagai kesalahan presentasi yang disengaja atas kondisi keuangan entitas yang dilakukan melalui salah saji dengan tujuan tertentu, atau penghilangan jumlah tertentu, atau pengungkapan pada laporan keuangan untuk menipu pengguna laporan keuangan.

Adapun International Standard on Auditing (ISA), khususnya ISA 240 The Auditor's Responsibility Relating to Fraud in an Audit of Financial Statement, menyatakan bahwa kesalahan penyajian pada laporan keuangan dapat disebabkan oleh kelalaian atau fraud. Perbedaan di antara keduanya terletak pada apakah terdapat unsur kesengajaan pada kesalahan penyajian tersebut.

Berbagai studi untuk mendeteksi financial fraud banyak dilakukan oleh peneliti dengan menggunakan fraud triangle analysis. Pada beberapa tahun terakhir, peneliti banyak menggunakan Beneish m-score model (Beneish, 1999, 2012), Dimitriosis (2014), data mining (zaki \& Theodoulidis, 2013), Ata \& Seyrek (2009), Altman z-score (1968), dalam melakukan analisa terhadap masalah ini.

Dalam studi ini, digunakan model Beneish m-score (Beneish, 1999) untuk mengestimasi kemungkinan adanya manipulasi. Model ini dikembangkan untuk mengukur potensi manipulasi dengan menggunakan variabel-variabel pada laporan keuangan, yaitu terdiri atas 8 rasio keuangan, yaitu DSRI, AQI, DEPI, TATA, GMI, SGI, SGAI, LEVI).

\section{Metode Penelitian}

Penelitian ini bersifat deskriptif dengan menggunakan data sekunder eksternal. Adapun yang menjadi obyek dari penelitian ini adalah Laporan Keuangan PT Garuda Indonesia, Tbk., tahun 2018, yang termasuk di dalamnya informasi mengenai posisi keuangan di tahun 2017, yang terdiri atas Neraca dan laporan Laba Rugi. 
Analisa yang digunakan untuk mengukur potensi manipulasi pada laporan keuangan perusahaan adalah model Beneish M-Score yang didasarkan atas 8 indikator, yaitu DSRI, GMI, AQI, SGI, DEPI, SGAI, LVGI, dan TATA. Model yang dikembangkan oleh M. Daniel Beneish pada tahun 1999 dan dikembangkan lebih lanjut oleh yang bersangkutan hingga tahun 2012 ini, mengungkap distorsi laporan keuangan yang bersumber pada manipulasi pendapatan, dengan penjelasan setiap indikator sebagai berikut:

- DSRI (Days Sales in Receivable Index); untuk memperkirakan adanya distorsi laporan keuangan dalam hal akumulasi yang diluar kebiasaan pada piutang. Dalam hal ini, DSRI merupakan rasio yang menggunakan 2 variabel, net receivable dan Sales, di tahun yang diukur $(\mathrm{t})$, dengan di tahun sebelumnya ( $\mathrm{t}$ 1). Kedua variabel ini mengukur apakah penjualan dan pendapatan dalam kondisi yang seimbang dalam dua tahun berturut-turut. Kenaikan DSRI yang sangat tinggi dapat disebabkan oleh perubahan kebijakan kredit untuk memacu penjualan dalam menghadapi persaingan usaha, akan tetapi peningkatan piutang yang tidak proporsional secara relatif terhadap penjualan dapat pula memberi kesan terjadinya peningkatan pendapatan. Peningkatan DSRI yang tinggi dapat pula menandakan adanya kemungkinan yang lebih tinggi bahwa pengungkapan pendapatan yang terlalu tinggi.

- GMI (Gross Margin Index); rasio untuk melihat adanya penurunan gross margin. GMI adalah rasio dari Gross Margin tahun sebelumnya (t-1) terhadap Gross Margin pada tahun yang diukur (t). Gross Margin Index lebih dari 1 mengindikasikan penurunan Gross Margin. Menurut Lev dan Thiagarajan (1993), penurunan Gross Margin merupakan salah satu sinyal negatif atas pospek perusahaan, dan perusahaan dengan prospek yang tidak bagus lebih berpotensi untuk terlibat dalam manipulasi pendapatan. Namun demikian, manipulasi persediaan atau beban produksi lainnya dapat pula menyebabkan peningkatan Gross Margin. Hal ini menunjukkan bahwa peningkatan dan penurunan Gross Margin dapat mengindikasikan kemungkinan terjadinya manipulasi.

- AQI (Asset Quality Index); Untuk mengukur potensi kapitalisasi biaya yang tidak biasa, AQI adalah rasio non-aset lancar selain PPE (Property, Plant, and 
Equipment) terhadap total asset yang mengukur proporsi total aset dengan manfaat di masa mendatang yang relatif kurang dapat dipastikan. AQI adalah rasio kualitas aset di tahun yang diukur (t), terhadap kualitas aset di tahun sebelumnya (t-1). AQI merupakan ukuran agregat dari perubahan dalam analisis risiko realisasi aset (Siegel, 1991). AQI lebih besar dari 1 menunjukkan peningkatan potensi terjadinya penangguhan biaya.

- SGI (Sales Growth Index); pertumbuhan penjualan yang tidak wajar dapat teridentifikasi dengan rasio ini. SGI adalah rasio penjualan pada tahun $\mathrm{t}$ terhadap penjualan pada tahun $\mathrm{t}-1$. Pertumbuhan tidak mengindikasikan adanya manipulasi, akan tetapi perusahaan yang tengah berkembang memiliki kecenderungan lebih untuk melakukan kecurangan dalam laporan keuangan yang disebabkan posisi keuangan dan kebutuhan akan modal (ACFE, 1993).

- DEPI (Depreciation Index); untuk mengidentifikasi penurunan nilai depresiasi yang terlalu besar. DEPI lebih besar dari 1 mengindikasikan penyusutan aset yang melambat, yang mana meningkatkan potensi bahwa perusahaan telah merevisi dengan menambah estimasi masa manfaat aset atau memberlakukan metode penyusutan baru yang cenderung meningkatkan pendapatan.

- SGAI (Selling, General \& Administrative Expense Index); peningkatan beban administrasi dapat mengindikasikan terjadinya penurunan prospek di masa datang. Rasio beban Selling, General and Administrative (SGA) terhadap penjualan pada tahun $\mathrm{t}$ dengan beban SGA terhadap penjualan tahun $\mathrm{t}-1$. Peningkatan penjualan yang tidak proporsional merupakann sinyal negatif tentang prospek perusahaan di masa depan.

- LVGI (Leverage Index); untuk mengukur ketergantungan pada pembiayaan berbasis hutang yang akan meningkatkan risiko finansial perusahaan dan potensi manipulasi pendapatan terkait dengan limitasi yang diatur pada perjanjian hutang. LVGI adalah rasio total hutang terhadap total aset pada tahun t relatif terhadap rasio serupa pada tahun sebelumnya (t-1). LVGI lebih besar dari 1 menunjukkan peningkatan leverage.

- TATA (Total Accruals to Total Assets)

Total akrual dihitung sebagai perubahan dalam akun-akun modal kerja selain kas dikurangi penyusutan. Total akrual terhadap total aset dipergunakan 
sebagai proxy sejauh mana kas yang mendasari laba yang dilaporkan, dan akrual yang tinggi / uang tunai yang sedikit, menggambarkan potensi manipulasi pendapatan yang lebih tinggi.

Tabel 1 : Model Beneish m-score

\begin{tabular}{|c|c|c|c|}
\hline Indikator & Deskripsi & Rumus & Bobot \\
\hline DSRI & $\begin{array}{l}\text { Days } \quad \text { Receivable } \\
\text { Index }\end{array}$ & $\begin{array}{l}\text { (Net Receivable t /Sales t ) / (Net } \\
\text { Receivable t-1/Sales t-1 )/ }\end{array}$ & 0,920 \\
\hline GMI & Gross Margin Index & $\begin{array}{l}{[(\text { Sales t-1 - COGS t-1 )/ Sales t-1 ]/ }} \\
{[(\text { Sales t - COGS t }) / \text { Sales t }]}\end{array}$ & 0,528 \\
\hline AQ & Asset Quality Index & $\begin{array}{l}\text { [1-(Current Assets } t+\text { PP\&E } t+\text { Securities t } \\
) / \text { Total Asset t }] /[1-(\text { Current Assets } t-1+ \\
\text { PP\&E t-1 + Securities t }-1) / \text { Total Asset t- } \\
1]\end{array}$ & 0,404 \\
\hline SGI & Sales Growth Index & Sales t / Sales t-1 & 0,892 \\
\hline DEPI & Depreciation Index & $\begin{array}{l}{\left[\begin{array}{lll}\text { Depreciation } t-1 / & / \mathrm{PP} \& \mathrm{E} \quad \mathrm{t}-1 \quad+ \\
\text { Depreciation } \mathrm{t}-1)] / & {[\text { Depreciation } \mathrm{t} /} \\
(\mathrm{PP} \& \mathrm{E} \mathrm{t}+\text { Depreciation } \mathrm{t})\end{array}\right.}\end{array}$ & 0,115 \\
\hline SGAI & $\begin{array}{l}\text { SG\& A Expense } \\
\text { Index }\end{array}$ & $\begin{array}{l}(\text { SG\&A Expense } \mathrm{t} / \text { Sales } \mathrm{t}) /(\text { SG\&A } \\
\text { Expense } \mathrm{t}-1 \text { / Sales } \mathrm{t}-1)\end{array}$ & 0,172 \\
\hline LVGI & Leverage Index & $\begin{array}{l}\text { [(Current Liabilities } t+\text { Total Long Term } \\
\text { Debt t ) / Total Asset } t] \text { / [(Current } \\
\text { Liabilities t }-1+\text { Total Long Term Debt } t \text { - } \\
\text { 1) / Total Asset } t-1]\end{array}$ & 0,327 \\
\hline TATA & $\begin{array}{l}\text { Total Accrual to } \\
\text { Total Asset }\end{array}$ & $\begin{array}{l}\text { (Income from Continuing Operations } \mathrm{t}- \\
\text { Cash Lows from Operations } \mathrm{t} \text { ) / Total } \\
\text { Asset } \mathrm{t}\end{array}$ & 4,697 \\
\hline
\end{tabular}

Adapun rumus model ini adalah sebagai berikut:

$$
\begin{aligned}
& \mathrm{M}=-4.84+0.92 \mathrm{DSRI}+0.528 \mathrm{GMI}+0.404 \mathrm{AQI}+0.892 \mathrm{SGI}+0.115 \\
& \mathrm{DEPI}-0.172 \mathrm{SGAI}+4.679 \text { TATA }-0.327 \mathrm{LVGI}
\end{aligned}
$$

Interpretasi dari model ini didasarkan pada perbandingan nilai $\mathrm{m}$-score dengan nilai acuan 2.22. Apabila $\mathrm{m}$-score lebih tinggi dari 2.22 (m-score > 2.22), maka berdasarkan model ini, dapat disimpulkan bahwa terdapat potensi manipulasi pada laporan keuangan perusahaan.

Penelitian ini menggunakan data laporan keuangan yang PT Garuda Indonesia, Tbk., yang telah diaudit, tahun 2017-2018. 


\section{Hasil dan Pembahasan}

Data dari laporan keuangan PT Garuda Indonesia, Tbk. (aset, ekuitas, dan kewajiban) diolah dengan menggunakan aplikasi Microsoft Excel. Hasil perhitungan kedelapan indikator tersebut dapat diuraikan sebagai berikut:

Tabel 2 : Hasil Perhitungan Beneish m-score

\begin{tabular}{|c|c|c|r|}
\hline Indikator & Bobot & Variabel & Bobot x Variabel \\
\hline Konstanta & $\mathrm{n} / \mathrm{a}$ & $\mathrm{n} / \mathrm{a}$ & $(4,84)$ \\
\hline DSRI & 0,920 & 2,438 & 2,24 \\
\hline GMI & 0,528 & 3,188 & 1,68 \\
\hline AQ & 0,404 & 0,939 & 0,38 \\
\hline SGI & 0,892 & 1,047 & 0,93 \\
\hline DEPI & 0,115 & 0,972 & 0,11 \\
\hline SGAI & $(0,172)$ & 0,861 & $(0,15)$ \\
\hline LVGI & $(0,327)$ & 1,054 & $(0,34)$ \\
\hline TATA & 4,697 & $-0,109$ & $(0,51)$ \\
\hline M-score $=$ Konstanta + $\mathbf{\Sigma}$ (Bobot x Variabel) $=$ & $(0,49)$ \\
\hline
\end{tabular}

Nilai Beneish m-score untuk PT Garuda Indonesia, Tbk. adalah 0,49, atau lebih besar dari -2,22, sehingga dapat disimpulkan bahwa berdasarkan model ini, terdapat potensi terjadinya manipulasi pendapatan pada laporan keuangan perusahaan untuk tahun buku 2018.

Di samping itu, variabel-variabel yang digunakan pada model ini atas data laporan keuangan PT Garuda Indonesia Tbk juga memberikan informasi sebagai berikut:

- DSRI; mengindikasikan terjadinya kenaikan rasio nilai piutang terhadap penjualan di periode 2017-2018 sebesar 9,4\%, di mana kenaikan nilai piutang yang signifikan hingga $150 \%$ tidak linier dengan peningkatan penjualan yang hanya naik sebesar $4,7 \%$, yang mana menunjukkan adanya kecenderungan terjadinya manipulasi pendapatan.

- GMI; menunjukkan gross margin tahun ini $(0,01)$ menurun hingga seperenam dari tahun tahun lalu $(0,06)$, meskipun dengan kondisi penjualan yang meningkat sebesar USD 195.851.289, dari USD 4.177.325.781 di tahun 2017, menjadi USD 4.373.177.070.

- AQI; menggambarkan bahwa peningkatan rasio aset (current asset, PPE dan Securities, terhadap total aset), tidak mengalami peningkatan yang berarti, yaitu hanya $2,85 \%$ 
- SGI; memperlihatkan bahwa rasio penjualan tahun ini dengan tahun lalu tidak meningkat secara signifikan, hanya 4,69\%, jika dibandingkan dengan peningkatan biaya-biaya yang terjadi.

- DEPI; rasio tingkat depresiasi memperlihatkan adanya peningkatan depresiasi tahun ini dibanding tahun lalu.

- SGAI; mengindikasikan terjadinya peningkatan biaya terkait penjualan $(10,9 \%)$ yang tidak linier dengan nilai penjualan yang hanya meningkat sebesar 4,7\%.

- LVGI; memperlihatkan bahwa rasio total hutang terhadap total aset mengalami peningkatan sebesar $4 \%$ pada kurun waktu satu tahun terakhir.

- TATA; menunjukkan nilai akrual yang tidak sigfinikan dibandingkan dengan nilai total aset perusahaan.

Sebagaimana model-model prediksi lainnya, hasil dari Beneish m-score hendaknya tidak dipergunakan sebagai hasil akhir dari investigasi, melainkan dimanfaatkan sebagai langkah awal dimulainya investigasi. Laporan Keuangan perusahaan yang memiliki potensi manipulasi menurut Beneish m-score perlu diuji dengan alat uji lainnya, meskipun model ini memiliki tingkat akurasi yang cukup baik, yaitu 77,1\% (Herawati, 2015).

Sebagaimana permodelan lainnya, Beneish m-score dapat menghasilkan 2 jenis kesalahan:

- Kesalahan menyimpulkan bahwa perusahaan yang memanipulasi pendapatan sebagai perusahaan yang tidak melakukan manipulasi

- Kesalahan menyimpulkan bahwa perusahaan yang tidak melakukan manipulasi pendapatan sebagai perusahaan yang melakukan manipulaso.

Berdasarkan penelitian ini dan berbagai literatur, terdapat beberapa limitasi penggunaan model Beneish m-score yang dapat diidentifikasi:

- Sektor usaha dan karakteristik perusahaan harus dipertimbangkan sebelum melakukan perhitungan dan analisa dengan model ini, mengingat model ini digunakan untuk perusahaan manufaktur dan jasa, namun tidak untuk perusahaan sektor finansial. Dalam hal ini, PT Garuda Indonesia Tbk., selaku perusahaan yang bergerak di sektor jasa, dapat dianalisa dengan menggunakan model ini. 
- Adaptasi dari indikator model ini atas kondisi laporan keuangan perusahaan di Indonesia harus dilakukan, seperti untuk indikator Income from Continuing Operations, agar dapat dilakukan analisa dengan model Beneish m-score.

- Perlu didefinisikan pendekatan yang standar untuk indikator yang tidak disebutkan secara jelas pada laporan keuangan PT Garuda Indonesia, Tbk., misalnya untuk Selling, General \& Administrative Expense (SG\&A), mengingat cukup sulit untuk melakukan kalkulasi atas Selling, General \& Administrative Expense ( $S G \& A$ ) pada laporan keuangannya.

\section{Kesimpulan}

Penelitian ini mengaplikasikan model deteksi manipulasi Beneish mscore atas laporan keuangan PT Garuda Indonesia Tbk untuk periode tahun buku 2018. Model ini menggunakan rasio-rasio keuangan yang menghasilkan 8 variabel untuk mengidentifikasi potensi manipulasi pendapatan pada laporan keuangan perusahaan. Hasil perhitungan Beneish m-score untuk laporan keuangan PT Garuda Indonesia Tbk adalah 0,49, yang mana lebih besar dari 2,22, sehingga dapat disimpulkan bahwa terdapat potensi manipulasi pendapatan pada laporan keuangan PT Garuda Indonesia, Tbk untuk periode tahun buku 2018.

Indikator DSRI, SGI dan LVGI mengindikasikan adanya perubahan yang signifikan pada piutang, penjualan dan hutang perusahaan dibandingkan periode tahun 2017-2018.

Penggunaan model Beneish m-score pada laporan keuangan perusahaan dapat memberikan manfaat bagi pemegang saham, investor, maupun kreditur, sebagai alternatif berbiaya relatif rendah untuk membaca kondisi berbagai perusahaan dan mengidentifikasi potensi adanya manipulasi guna investigasi lebih lanjut.

Adapun keterbatasan penelitian ini adalah sebagai berikut:

- Meskipun model yang dipergunakan dalam penelitian ini merupakan alternatif yang efisien dari segi biaya, perlu diperhatikan pula bahwa distorsi yang diukur dapat pula dihasilkan dari berbagai aspek yang wajar dalam operasional perusahaan, seperti adanya akuisisi yang material 
selama periode pengujian. Oleh karena itu, verifikasi lanjutan dengan berbagai metode, perlu dilakukan.

- Model yang dipergunakan hanya dapat diaplikasikan pada perusahaan yang telah diperdagangkan sahamnya di bursa saham, dan mungkin tidak dapat diaplikasikan pada perusahaan-perusahaan yang tidak masuk bursa.

- Di samping itu, karena pengukuran yang dilakukan adalah terhadap lebih saji dan kurang saji (overstated dan understated), model ini mungkin tidak akan terlalu handal untuk mempelajari perusahaan di mana kondisi ataupun industri yang melingkupinya tengah dalam situasi penurunan pendapatan.

\section{Referensi}

Association of Certified Fraud Examiners (ACFE). 2015. "International Fraud Examiners Manual". Washington : ACFE.

INTERNATIONAL FEDERATION OF ACCOUNTANTS. 2009. "International Standards on Auditing (ISA), 240, The Auditor's Responsibility Relating to Fraud in an Audit of Financial Statements". New York : IFAC.

Tarjo, N., H. 2015. "Application of Benesih M-Score Models and Data Mining to Detect Financial Fraud". Procedia - Social and Behavioral Sciences.

Beneish, M.D. 1999 “The Detection of Earnings Manipulation”. Financial Analyst Journal, Vol.55.

PT Garuda Indonesia. 2018. Laporang Keuangan Tahunan 2018 (Audited).

PetriK, V. 2016. "Application of Beneish M-Score on Selected Financial Statements". (online). Available at https://www.researchgate.net/publication/311733912.

Beneish, M.D., Nichols, D.C. 2007. “The Predictable Cost of Earnings Manipulation”. (online). Available at https://papers.ssrn.com/sol3/papers.cfm?abstract_id=10006840.

Weygandt, Jerry J., Paul D. Kimmel, Donald E. Kieso. 2016. "Financial Accounting". $3^{\text {rd }}$ Edition, John Wiley \& Sons, Inc.

Tuanakotta Theodorus M. 2007. “Akuntansi Forensik dan Audit Investigasi”. Lembaga Penerbit Fakultas Ekonomi dan Bisnis Universitas Indonesia.

Elder, Randal J., Marks S Beasley, Alvin A. Arens, Amir Abadi Jusuf. 2008. “Auditing and Assurance Services, An Integrated Approach - An Indonesia Adaptation". Penerbit Salemba Empat. 